\title{
“LA EDUCACIÓN ES IMPORTANTE": SOCIO-EDUCATIONAL EXPERIENCES AND GENDER DYNAMICS AMONG YOUNG MOTHERS ATTENDING COLLEGE
}

\author{
Beatriz Alvarado \\ alvarado.24@osu.edu \\ University of Massachusetts - Estados Unidos
}

Recibido: 20-02-2012

Aceptado: 10-03-2013

\section{Resumen}

El cuidado de una criatura conlleva una gran responsabilidad, y la misma se torna aún mayor si se añaden otras tareas. El presente artículo describe las experiencias socio-educativas de un grupo de mujeres de bajos ingresos económicos, quienes son las primeras en sus núcleos familiares en seguir estudios universitarios, tanto en universidades privadas como públicas en Perú y México. Estas mujeres no sólo son responsables por el bienestar de sus hijos sino por mantenerse como estudiantes de tiempo completo en la universidad. Este estudio analiza cuatro temas principales: participación del núcleo familiar en el cuidado infantil; presión académica y ayuda del sistema educativo; creencias socio-culturales acerca de roles femeninos y cuidado de menores; y visión de las participantes acerca de sus futuros sociales y profesionales. La autora sugiere que es importante otorgar mayor atención a las necesidades socio-educativas de estas mujeres con el fin de ayudarlas a conseguir sus objetivos de vida en una sociedad enteramente patriarcal.

Palabras clave: maternidad, mujeres universitarias, sistema educativo, nucleo familiar, cuidado de menores, roles de género, roles masculinos.

\begin{abstract}
Childcare is already a difficult job, which can become even more stressful if other responsibilities are added. This article describes educational and social experiences of lowincome women who are mothers and first-generation college students in both private and public educational institutions in Peru and Mexico. These women are not only responsible for their children's well-being, but also struggle to maintain their status as regular full-time students. Four main themes are analyzed in this study: Familiar participation in the childcare, school pressure and educational system support, socio-cultural beliefs about women's roles and childcare, and participants' views of their professional and social futures. The author suggests that more attention needs to be provide to these women's socio-educational needs, for them to attain their goals in an already unfriendly patriarchal societal context.
\end{abstract}

Keywords: motherhood, college women, educational system, family members, childcare, gender roles, male roles. 


\section{Introduction}

During the last two decades, higher education in Latin America has gone through an important expansion; however, there are still substantial differences among countries of the region in terms of education for all (Aguilera, 2009). For instance, in countries like Argentina and Costa Rica, students' enrollment in higher education is comparable to some European countries, but Bolivia, Perú and Guatemala are still struggling with illiteracy levels that have a serious impact on an important group of citizens: rural women and indigenous people (Stromquist, 1992). Social and educational gaps between rural and urban areas are persistent. Dropout and grade repetition rates are higher among the poor and those living in rural areas. Macedo et al (2003) state that the $10 \%$ wealthiest Latin American heads of household have an average of 12.1 years of education; in contrast, the $30 \%$ poorest Latin American heads of household have an average of only 5 years of education. Also, in terms of access and completion of basic education, girls have not benefited as fully as boys.

Research on rural women in Latin America states that they are at a greater disadvantage educationally than women living in cities, due to linguistic, cultural, and economic disparities (Chung et al, 2001). On the other hand, CEPAL (2004) reports on the region highlighted a gap between female students' educational achievements and their opportunities in the work market, where they experience a significant disadvantage. This gap reflects the weaknesses of the school's impact on the distribution of responsibilities in the household, leading to discrimination against women. For instance, high school dropout and grade repetition ratios are mainly due to the early responsibilities that girls assume at home since school has not been designed for rural groups (Hidalgo, 2004; Montero y Tovar, 1999).

Within this critical socio-cultural context, in which millions of Latin American women are immersed, access to higher levels of education can be challenging; however, throughout the years, women, mainly in urban areas, are progressively entering the historically maledominated realm. The inclusion of women in higher education increased significantly in the region during the eighties; women comprised $40 \%$ of enrollment. In countries like Peru and Mexico this percentage has been growing, but despite the fact that the presence of women in higher education constitutes an important step in these societies highly influenced by patriarchal hierarchies, this presence has not necessarily implied substantial or dramatic changes, neither in academic institutions nor in the power of decision making, which still remains a man's territory. So here is the apparent contradiction: a young, single Latin American mom from a low-income family faces many financial constraints. In this position, it is unlikely that she will achieve a dream job in her lifetime. So why attend college?

Little is known about the experiences of young women who are both mothers and college students in Latin America. There is a large number of reports and statistics on men and women's access to education, access to workforce, household responsibilities, and public policies on gender equity (Argüelles et al, 2004; CEPAL, 2008; Montaño, 2007, Corvalan, 
Socio-educational experiences and gender dynamics among young mothers attending college

1990), but they do not capture the deep understanding which a qualitative inquiry would bring to this issue. The literature on low-income, first-generation college students who are mothers and their multiple dilemmas is virtually non-existent. The aim of this study is to describe the experiences of these young women, who are mothers and full-time students in both private and public colleges in Southern Peru and Northern Mexico.

An important motivation for this study was my experience as a former college instructor of these young mothers in Peru and witnessing their multiple challenges and constraints throughout the academic year. Four questions guided the data collection and analysis: how do Peruvian and Mexican cultures and kinships shape the socio-educational experiences of young mothers pursuing a college degree?; how does the educational system influence the failure or success of these women at college?; how do the women perceive their roles as professionals and mothers in the future?; and what is their motivation to stay in school in spite of numerous socio-cultural, financial, and educational challenges? This article uses a feminist perspective to examine the educational and socio-cultural experiences of young women who are mothers and college students in Peru and Mexico.

In this sense, Flax (1997) pointed out that the main goal of the feminist approach is to analyze gender relations, in particular how these relations are constituted and experienced in terms of the situation of women and the analysis of male domination. Furthermore, in her account of feminist approach's categories, Tisdell (1995) described a feminist approach able to facilitate women, as individuals, to gain access to systems to which men have historically had access, and also to give women equal opportunities with regard to education and the job market. This notion is connected to Dentitth y Brady's (2001) postmodern feminist theory, which explores the relations of power within economical, historical and social contexts and recognizes the unfairness of many gendered social practices. The experiences of young women in this study present a constant tension between what society expects from them, and what they really want to accomplish in life despite the oppressive social and cultural contexts.

\section{Women's educational experiences}

Research on professional women in South America found that university experience increased their cultural capital and is a significant means of socialization, but offers very little when it comes to readiness to enter the labor market and actively participate in the social and political arenas (Corvalan, 1990). Furthermore, the admission of women into 'male career domains' in areas such as medicine, law and engineering show that not always the best level of education corresponds to higher wages and more management positions. Despite the increase of women in higher education in Latin America, research on the experiences of young women who are both mothers and full-time students is absent. Studies mostly focused on issues of women's work productivity with regards to national economies, practically ignoring the 
domestic environment and other motherhood responsibilities that seriously impact their professional and personal lives.

The experience of thousands of women in the region, as in many parts of the world, is that getting a college diploma does not guarantee a profitable job opportunity. One group of women gives up their careers when they get married and start having children; the other group faces serious limitations to its career development and struggles finding balancing roles as mother, wife and professional individual (Stalker, 2001). In her description of the feminization of higher education, Correa (2005) stated that with regard to inequality in access to education, gender roles continue to play the strongest role.

In the particular case of Mexico, data from 1990 to 2000 on undergraduate and graduate higher education programs revealed that women's enrollment had increased. This is good news from an economic point of view since individuals with higher levels of education have better employment prospects. Garcia (2008) argued that in Mexico, individuals who hold a higher education diploma are ten times more likely to find a job than those who do not. Furthermore, a report by the National Institute for Women shows a rise in female participation in the workforce from $17.6 \%$ in 1970 to $42 \%$ in 2000 . However, women still dominate occupations such as health, education, and catering, which have lower status and payment.

Women in Mexico now have a significant presence in higher education but there continue to be more women who choose liberal arts, social sciences, and health programs over other programs offered. Interestingly, Garcia (2008) stated that female enrollment in traditionally "feminine" programs is due in part to the opportunities these professions hold for flexible work schedules, allowing women to combine family and career. Moreover, the choice of liberal arts programs by women is shaped by the social construction of gender established by the patriarchal society. Traditionally, in Mexican society women hold family and domestic functions, while men are responsible for the household economy, working outside the domestic sphere.

It is widely known that the second half of the twentieth century will be recalled in history as the era of higher education expansion. Globally, the number of students enrolled increased from 13 to 82 million between 1960 and 1995 (UNESCO, 1998). In the case of Perú, in the past 25 years, female enrollment in higher education has risen substantially. In the 1960s there were 3.4 men for each woman enrolled; in 2002 the ratio dropped to 1.2 men for each woman enrolled (Universia, 2005). The country also experienced what is called masificación de la educación, meaning that more people of lower social and economic backgrounds were able to enter this field (López, 2007). Moreover, the number of Peruvian universities has grown significantly in the last decades. By the 1970s Peru had 10 universities, one of which was private; by the year 2000 there were 91 universities, 35 public and 56 private (Foro Educativo, 2001).

Caplan (1994) argued that there are more women than men at lower educational levels in universities in general, but this number decreases at higher graduate levels. While women and men are enrolled in almost equal numbers in higher education, studies have shown that higher education does not necessarily guarantee that women attain equal status or academic and working opportunities in society (Niddifer y Bashaw, 2001). It has also prevented them 
from fully exercising their rights to pursue a college degree in an educational environment sensitive to their needs as young mothers, who are primary caregivers of their children and responsible for domestic duties. For young mothers who decide to "take risks" and enter an unfriendly educational environment, it is imperative that they be surrounded by a strong social and family network; otherwise, their lives are usually a continuous struggle between their education, childcare and domestic responsibilities (Campbell, 1993).

Women in different cultures undergo similar concerns about their learning experiences. These concerns are mostly about their academic and work expectations, conflicts in motherhood, responsibilities as students, and lack of support from their partners (Belenky et al, 1997; McFarlane et al, 2000). Crittenden (2001) states that societal messages constantly 'remind' women that they are entirely responsible for their children's fate; otherwise they will be blamed if their children fail to fulfill society's expectations. This causes more tension among women's decisions to continue their education or confine themselves within a domestic sphere.

Childcare, housework, and for many, work responsibilities take much of the time needed to be dedicated to studies, drawing young mothers away from the educational environment, leaving them unable to participate fully in aspects of school life such as study groups, group assignments, and other activities. Fagan (1991) pointed out that the decision of women to continue their education can, to some degree, affect family patterns and lead to friction with male partners, who sometimes manifest abusive behaviors. Thus, looking for help and to reduce the stress that parenting and their education can involve, many women rely on friends and relatives, mostly grandmothers, as a trusted and reliable support for their childcare. Kalil y Danziger (2000) indicated that grandmothers might alleviate some stressors and help young mothers continue their education. In her study on African American women, Collins (1990) also described women's role of caring for the children of extended family, friends, and neighbors. She calls it "other mothering," meaning helping to fill the gap created by unaffordable childcare, economic hardship, and overworked parents by caring for children other than their own.

The socio-cultural beliefs of women's roles explored in this article also involved unplanned pregnancies and how they are stigmatized by communities. There exists limited research on this topic that derives from observation, interviews, and interpretations and focuses on the Latin American region. Childbearing practices and beliefs are other important elements to consider when studying women in Peru and Mexico. Even though traditional practices of childbearing are mostly followed by rural people, urban areas are highly influenced by these practices because of migration waves from rural centers to cities. Furthermore, grandmothers are key agents in preserving ancestral practices and passing them to their children and grandchildren. For instance, swaddling the baby is a frequent practice that young mothers do, learned from their grandmothers or even women neighbors. This practice is linked to a belief that children who are closely bound will grow up strong and straight (DESCO, 1992). From the overwhelming roles of being a mother and a student, dealing with countless societal gender roles and expectations, to cultural and traditional practices of childcare, women are immersed in a system that demands much of them. 


\section{Methodology}

This exploratory and descriptive qualitative inquiry identifies and describes educational and social experiences of twelve low-income women who are mothers and first-generation college students in both private and public educational institutions in Peru and Mexico. The participants were 20-24 years old and met the requirement of being mothers and full-time students. The participants of this study were Peruvian and Mexican mothers with one or more children of less than three years of age.

The students selected for this study were enrolled in educational institutions located in the Southern region of Peru and Northern Mexico. They were students of education, business and accounting. I personally interviewed nine participants from two private and two public colleges in Peru. Participants from Mexico were interviewed by a faculty colleague who works with them. These participants were from public institutions. I chose the sample considering the socio-cultural contexts of both countries and expecting that a diverse sample would provide rich information in regard to educational systems and programs, location, socioeconomic level, family support in childcare, and women's roles.

Participants in this study lived with their parents. None of them reported living with the child's father. As for their family educational background, none of their parents have a college degree, which makes the participants first-generation college students. Participants were in the last two years of college, and they expressed the willingness to graduate at some point in spite of multiple obstacles.

Data collected came mostly from interviewing students individually, and also by conducting participant-observations in the students' educational settings in Peru. Data gathered in Mexico was primarily based on interviews with participants. I reviewed institutional documents about the socio-economic and educational backgrounds of the students. The semistructure interviews were carried out on campus, mostly at the library, and conducted entirely in Spanish. Each interview lasted one hour, and was audiotaped, transcribed and analyzed using the constant comparative method (Creswell, 2006). Throughout the interviews, participants shared thoughts, beliefs, and dilemmas of being mothers with many domestic responsibilities while maintaining full-time student status.

\section{The real cost of attending college: Findings and Discussion}

This study analyzed the educational and socio-cultural experiences of 12 young college mothers enrolled as full-time students in Peru and Mexico. These women were in the last two years of their studies, which is an important indicator of their willingness to graduate. None of the participants lived with the child's father and four were working in part-time jobs. When 
asked about the relationship with the child's father, all of them stated that they got pregnant while they were in a serious relationship which ended after they found out they were pregnant. Four of them reported living with the child's father for a few months before and after having the baby, but the relationship "did not work out" as they hoped. Of the 12 participants, only five reported getting some kind of voluntary financial support from the child's father. None of them have moved to legally demand child support from the father, even though in these two countries, unmarried women have the right to do so.

The young women were all living in their parent's houses and getting financial support from them. For the ones that worked part-time, their wages did not exceed 90 dollars per month. Financial government assistance for childcare is non-existent in these countries. There are centers funded by the central government, Wawawasi, where working moms can bring their babies during the day, but they are usually crowded and very small places, according to the participants. None of them took their babies to those places.

These women's experiences as mothers and college students were organized according to four categories and consecutive sub-categories:

\subsection{Kinship participation in the childcare}

Grandmothers and female relatives are usually the most trusted member of the family able to take care of the child while the participants attended classes or went to work. These people were the most trustworthy in addition to being the most loving and likely to keep the child safe and fulfill her/his needs. Participants expressed feeling relieved at having their mothers and other female relatives being part of their lives at this time:

“I couldn't do this without the help of my mom. I feel she knows my child more than I do. My child loves his grandma and he stopped being sick after being in her care. Before I left him with an aunt and he fell down and was sick all the time. My mother used to live in another town but she had to move here because of what happened to me [having the baby]. She rented a small apartment and I am living with her now. My dad and my siblings are still in the other town, but I think all this change will be temporary until I graduate" (Maria, 20; 1 year-old child).

This "what happened to me" had an important repercussion in these young women's family structures. The new baby's arrival shook their families' organization and also changed their roles unexpectedly. Interviewees expressed that the new baby brought happiness but also some tension within their kinship structure.

"I feel blessed to have my sister helping with my baby. We take turns taking care of her. My sister works night shifts so she can stay with my kid during the day. Sometimes she gets upset with me because she can't do other things like studying or going out because of the baby. I can't pay her for her help now but I will compensate when I graduate and find a job. Both of my parents work the whole day but they help me a lot financially" (Bety, 20; 1 11/2 year-old child). 
The participation of male family members or the child's father in the care of the child was not even mentioned by the participants. When asked about this absence, participants mentioned that the men were busy working or they avoid such activity, considering it to be a woman's duty.

\subsubsection{Family financial support}

Family financial support was a key issue for these young women in order to maintain their babies and keep attending college. All of them reported getting pregnant from their boyfriends while in college but only five got limited financial support from them. Grandparents became responsible for the baby's expenses and also for paying the college tuition of their daughters. It is important to note that about four participants attended private colleges. These colleges charge about forty dollars a month for tuition, a tiny amount in our eyes, but one which caused an impact on their families' already limited economies.

"I feel bad having my parents supporting me and my baby. I thought that my life was going to be different but I got pregnant and everything changed. Now my father has another responsibility, he spends a lot on the baby, especially when the baby gets sick. The dad always finds excuses for not giving me any money" (Ana, 20; 2 year-old child).

"I get a very low wage in my part-time work at the local bookstore, less than 150 soles [49 dollars] per month. I need to rely on my parents' help to maintain my baby and myself. Sometimes I get some money from my baby's stepmother as well. My baby's father claims that he is also a student and cannot help me. I hope to find a better job and take care of my baby without bothering my parents" (Clara, 22; 3 year-old child).

Family financial support represented constant tension for these mothers who see they have increased their family budget expense by adding another unplanned little member.

\subsubsection{Father's role in childcare and relationship with the mother}

The father's role in childcare and relationship with the mother was not only another cause of tension for the participants of this study but also for their families. Only four participants claimed to have a good relationship with the child's father. The rest expressed their frustration because of the lack of financial and moral support. They recalled having fights with their former partners that escalated into fights between the child's father and the mother's parents. Two participants referred to being blamed by their former partner's mothers because she got pregnant and "destroyed her son's life." The son incidentally did not provide any kind of support to the child.

"I do not want to talk about him [the father]. He practically disappeared from our lives. I don't get any kind of support from him. He does not visit his daughter and does not care about what 
Socio-educational experiences and gender dynamics among young mothers attending college

happens to her. Every time we have met, we ending up fighting hard and I don't like that" (Sofi, 20; 1 year-old child).

Trying to obtain financial support from their former partners was not the only source of tension among these women; they recalled being insulted for not knowing how to do "women's stuff" like cleaning or cooking while living with the partners. They were also hurt by the fathers with respect to body image, being called gorda, fea and barrigona [fat, ugly and potbellied] while being pregnant.

"He insulted me because of my figure. I was really fat when I was pregnant because I was depressed living with him, far away from my family, and so I ate all the time. His mother also called me names because I did not know how to do household chores the way she wanted. One day I decided to return to my parent's house and that was the end of my relation with him" (Katy, $22 ; 3$ year-old child).

It is not uncommon to find grandfathers legally registering as the biological fathers of their grandchildren because the real father simply disappeared or denied his paternity.

"When I told him I was pregnant, he got furious and said he was not the father. He was my first man but he denied being the father of my child. My father had to assume the legal paternity in order to report my child's birth and get him a last name. I felt so betrayed and upset with life and myself" (Flora, 21; 1 year-old child).

Being a single mother, living in their parent's home, depending financially on them, and getting help from their female relatives put these women in "uncomfortable positions," as some of them expressed. They reported feeling that they had to overwork to show their families they were, as adult individuals, able to take care of their children and to study at the same time. For most of them, the day did not end after school or work but they had many responsibilities waiting for them at home such as washing baby clothes and diapers [for many by hand], cleaning the house and feeding and spending time with their babies.

\subsection{School pressure and educational system support}

The responsibilities just described took much time away from participants, giving them little time to complete college assignments and putting them behind their classmates. They also reported staying up until late to complete their assignments. The cries of an upset or sick baby often made them stop their homework altogether. This impacted their academic performance, especially if they did not have understanding faculty members or a supportive educational system.

“Tengo muchas tareas!: Faculty support to young mothers". 
Too many assignments were one of the main concerns and complaints among the participants. Due to their responsibilities at home with their children and, for some of them, additional responsibilities at work, school assignments could be overwhelming, causing anxiety and frustration.

"This is too much for me. I don't only have to finish school projects, get prepared for exams, and finish my student-teaching assignment, but I also have tons of things waiting for me at home. Teachers do not care about our situation as mothers; they treat us as any other students. I am not asking for special treatment, but they do not want even to listen our problems" (Erica, 23; 2 yearold child).

Female instructors caused more pain than relief to the participants' academic experience. According to the interviewees, these instructors did not show any kind of concern for their situation, even when a sick baby was involved.

I told her my baby was very sick and she did not give any extension to turn in my project. She also said 'who in the world tell you to have a baby? She does not have children, that is maybe the reason she doesn't understand us. Most of our female instructors are always like upset with us [mother-students]. I feel our condition as mothers bothers them a lot (Elena, 20; 1 year-old child).

Family support was not $100 \%$ available all the time, so participants recalled taking their babies to classes which made their teachers and classmates uncomfortable.

I had to take my child to one of my classes since I had a presentation that day. My baby is a quiet child but that day she was a little fussy. She [instructor] was really bothered as well as some of my classmates. I understand it wasn't a good idea but I didn't have any other choice. Unfortunately, there is not any daycare facility at school; this would really be of much help for mothers (Maria, 20; 1 year-old child).

Daycare facilities and a more supportive academic environment for young mothers are what all participants desired at their college. Furthermore, they voiced the need for a system that understands their condition as mothers with many responsibilities, but with the willingness to finish school as any other student and then go on to find a job after graduation. It is obvious that the school system has not been designed for these women; on the contrary it makes their success at school harder and even impossible. Phrases like "women are not supposed to study after they have children" from one male instructor, send clear messages to these women about their expected role from society. They also imply that women are less tied to academic work, the priority being their roles as mothers (Gouthro, 2002).

\subsection{Socio-cultural beliefs about women's roles and childcare}

As indicated, faculty members tended to perpetuate societal beliefs about women's roles, as participants stated in this study. Statements like "once you are a mother, you need to behave as a mother" imposed a stereotypical role on these student-mothers. Likewise, the lack 
Socio-educational experiences and gender dynamics among young mothers attending college

of daycare facilities at the school sends a strong message to mothers who dare to leave the domestic environment looking for an academic degree. These messages about gender roles are not only heard in academic settings but also within the participants' kinship and communities.

"Eres una mujer [you are a woman], don’t forget it!"

Participants reported being constantly harassed by some friends and relatives about their decision to keep studying and getting a college degree. As previously noted, female relatives were of much help in offering childcare to the participants; however, they were also messengers of what a woman's role should be, particularly grandmothers and aunts.

"My mother helps me so much with my kid, I appreciate all her support but she constantly tells me about what I should be doing at home instead of spending lot of hours at school. I feel she wants to help me but she would be happier if I stayed at home and had a normal family life" (Marly, 22; 1 year-old child).

"I am 24 and I am criticized by my friends about my stubbornness about continuing to study instead of looking for a husband and living a regular life. It is really hard in this town to be a woman trying to follow your dreams. There is a very strong machismo around here. Men are supposed to be the ones with a profession and a great job while women have to take care of the house. I've seen that since I was a little girl and I don't think it will change soon" (Meche, 24; 2 year-old child).

According to participants, male relatives found it interesting that women got some kind of higher education, but when it came to women who graduate and look for a job outside home, they felt their male authority was lessened.

"My father and my brothers were happy when I entered college, but they thought I was going to
quit when I had my baby in order to take care of him. They thought I would go to live with my
partner, but it didn't happen. My father stopped helping me with my college tuition and asked me
to make up with my child's father and "behave like an adult woman," but I decided to work to
pay for my tuition. He still helps me with my baby's expenses and with many other things. I don't
think he is happy about what I decided to do with my life" (Pilar, 23, 2 year-old child).

These participants' experiences resemble Fagan (1991) and Crtittenden's (2001) description of women and how their expected roles impact family patterns when they decide to take a different path in their lives and become independent agents.

Another emergent theme of particular importance is the influence on these urban participants of traditional beliefs about childbearing practices. Even though these women in both countries were born in urban areas and were currently studying in urban colleges, most of them strongly believed in traditional rural practices to treat their children when sick or to care for them. For instance, the practice of swaddling the baby (DESCO, 1992) was found very frequently performed by these young mothers. When asked about who taught them to do it, they indicated their grandmothers and mothers did. As previously stated, this practice is linked to a belief that children who are closely bound will grow up strong and straight. 
"If I didn't swaddle him when he was born and even after, he was like a jellyfish moving his body all over the place. My grandma taught me to do it. I thought it was only indigenous women did this, but it was good for my baby and helped him to grow up straight" (Bety, 20; 11/2 year-old child).

When their child was sick, participants mentioned going to a traditional doctor (natural healer) first. This was mostly because of relatives' bad experiences with mainstream medical doctors: "my aunt went to a doctor at the hospital and they said she did not have anything serious and a few weeks later she died". Two participants mentioned taking their babies with severe stomach pain to traditional healers because they had certain way to cure it. What these healers did was to turn the baby upside down and move the legs back and forth. "That was a great thing, my baby stopped crying and it was the end of his pain". Another important reason these women preferred to take their babies to traditional doctors was because they did not have to wait for weeks to get an appointment and the service fees are much lower than those of regular doctors.

\footnotetext{
"My baby cried for more than a week and had diarrhea and stomachache. I took her to the clinic and they gave her a medicine but it didn't work. My neighbor brought us to this curandero [traditional doctor] and with some movements and herbs, he cured my baby. I wasted my money with the other doctor, but this one really helped me" (Gladis, 23; 3 year-old child).
}

There are also ways to protect their children from "outside negative forces" such as mal de ojo (Myers, 1994). Mal de ojo or evil eye is believed to be a cause of sickness, which most commonly affects babies. It is defined as a hex caused by a gaze from a stronger person looking at a weaker person (usually a baby). One means of protection is by attaching a red ribbon to the baby in order to 'direct the gaze' to the ribbon.

As described in this study, these inexperienced, single mothers are burdened with financial constraints, criticized within their family and social circles, and unsupported by an unfriendly school environment; these women row against the current of a society that clearly sends constant messages of their "inability" to do certain things that are deemed more appropriate for men and single childless women.

\subsection{Participants' views of their professional and social futures}

In spite of these obstacles, all the participants expressed their intention to be a role model for their children and find a job that makes them independent individuals able to support their children and also their immediate families. There is a strong moral, spiritual and material interdependency between them and their families, as indicated during the interviews. But how do they see their futures? Where do they see themselves in a few years?

\footnotetext{
"I very urgently want to finish my studies, the soonest the better. There were times that I wanted to forget about everything and just take care of my baby and depend on my parents, but I see my other classmates that are mothers as well, and they keep going ahead despite tons of problems we face. I want to graduate and find a job which helps me to repay my parents for all that they have done for me and my son" (Elena, 20; 1 year-old child).
} 
Even though there was not an evident support network among participants, each one's willingness to stay in school serves as inspiration within the group. When asked about their job opportunities in these countries -Peru and Mexico- that have a high level of unemployment and limitations for women who have children, they expressed their fears but this situation did not sway them from their objectives.

"I know it is really hard to find a job nowadays. I know people that are good professionals and are unemployed. But if I don't graduate I will have less opportunity to find a job, I know that. I talked with other classmates and maybe we will set up our own business, who knows" (Claudia, 22; 2 year-old child).

As to their lives with another partner, only three participants see themselves as having someone in their future. Based on the painful experiences with their former partners, all other participants did not foresee their lives with another man.

"Having a new man in my life? Never again. It was a very bad experience that I don't even want to remember. I just want to finish my studies, find a job and live a calm life with my son and my family. I know I made a huge mistake trusting that guy [child's father], he seemed a nice person but when he knew I was pregnant, he became another person. I am very disappointed in men" (Rosa, 21; 2 year-old child).

These women's motives to persist at school in spite of multiple obstacles go beyond a personal desire; their main reason for continuing is their children and their desire to be a model for them. "I don't want my child to experience what I went through," and "I want her to be proud of her Mom". These desires should not be taken lightly; there is an urgent need to provide support for mothers attending college at the national and state education levels in order to make everyone aware of the importance of educating these women to help them be active members of society.

\section{Conclusions and recommendations}

Twelve participants in this study described their experiences as mothers and college students in Peru and Mexico. The results of this study are limited to young Southern Peruvian and Northern Mexican mothers enrolled in private and public education with specific socio-educational problems which are then analyzed in this research. Results cannot be generalized but provide an important understanding about young mothers and their socio-educational dilemmas while pursuing a college degree. 
Findings from this study indicate that is spite of the multiple obstacles they find performing their responsibilities as mothers and students, they are determined to finish their studies and become independent agents able to be role models for their children and pay back their families for college support.

As detailed throughout the study, these mothers' first priority was the wellbeing of their children, so it is critically important that educational norms be established that can provide these mothers with flexible deadlines and daycare facilities at college. This would facilitate their spending more time with their children, particularly those at a breastfeeding age, and also prevent mothers from falling behind in their academic process.

Faculty and college authorities should be made aware of multiple dilemmas faced by mothers so that they could better support them in their educational endeavors and have a hand in their ultimate academic success. Findings in this study showed that instructors, particularly female, are insensitive about the participants' schedule conflicts. Workshops should prepare instructors to deal with this special group of students.

Stereotypes and expectations about women's roles in society are not liable to change any time soon, particularly in these two countries, where machismo is an important component of societal organization. Thus, primary and secondary schools should be places where students are taught to respect differences and equally value women's and men's contributions to the society. Furthermore, curriculum and teaching practices should incorporate feminist and inclusive teaching perspectives (Gouthro, 2002) to achieve a more equitable education.

As for the children's fathers, no participants indicated plans to legally demand child support. This inaction allows irresponsible fathers to disappear from their children's lives. College financial offices should step in to provide support for young mothers in order that they receive fair financial assistance that covers their basic needs.

Future research should focus on the emotional and psychological impact of childbearing and college experiences of young women and their nuclear families. Additionally, future research on student mothers should explore the experiences of these women after graduation and entering the labor market, an area by and large designed as men's territory.

\section{Acknowledgment}

Many thanks to Dr. Paula Guerrero for her substantive contribution to this article with the interviews to the Mexican participants. 


\section{BibLiOgRAFía}

- Aguilera, Teresa (2009): "Plan Rector de Desarrollo Institucional, 2009-2013", [en línea] Disponible en: http://www.uaemex.mx/planeacion/InfBasCon/ContaduriayAdministracion/ PlandeDesarrollo/2009-2013/PLAN_ADMON\%20Y\%20CONT.pdf [10/01/2013].

- Argüelles, Ana Rosa; Martínez, Carolina y Menéndez, Paz (2004): Igualdad de Oportunidades y Responsabilidades familiares. Madrid: Editorial Consejo Económico y Social.

- Belenky, Mary F.; McVicker, Clinchy B.; Rule Golberger, Nancy y Mattuck Tarule, Jill (1997): Women's Ways of Knowing: The Development of Self, Voice, and Mind. New York: Basic Books.

- Campbell, Patricia (1993): No Going Back: Women as University Students. Halifax: Fernwood Publishing.

- Caplan, Paula (1994): Lifting a Ton of Fathers: A woman's Guide to Surviving in the Academic World. Toronto: University of Toronto Press.

- CEPAL - Comisión Económica para América Latina y el Caribe (2004): Caminos hacia la Equidad de Género en América Latina y el Caribe. $9^{\mathrm{a}}$ Conferencia Regional sobre la Mujer de América Latina y el Caribe. México, D.F: CEPAL.

. (2008): "Panorama Social de América Latina", [en línea] Disponible en: http://www.eclac.cl/cgi-bin/getProd.asp?xml=/publicaciones/xml/2/34732/P34732.xml\& $\mathrm{xsl}=/ \mathrm{dds} / \mathrm{tpl} / \mathrm{p} 9 \mathrm{f} . \mathrm{xs}$ \&base=/dds/tpl/top-bottom.xslt [10/01/2013].

- Chung, Carmela; Straatman, Rosa; Quispe, Maricela y Reynaga, Gumercinda (2001): Menarche and its Implications for Educational Policy in Perú. Ayacucho, Perú: Red Nacional de Promoción de la Mujer.

- Collins, Patricia (1990): Black Feminist thought: Knowledge, Consciousness and the Politics of Empowerment. Boston: Unwin Hyman.

- Correa, María (2005): La Feminización de la Educación Superior. Bogotá: Tercer mundo editores.

- Corvalan, Graziella (1990): Mujer y Educación en América Latina y el Caribe. Cuadernos de Discusión. Asunción: Centro Paraguayo de Estudios Sociológicos.

- Creswell, John W. (2006): Qualitative Inquiry and Research Design: Choosing among Five Approaches. Los Angeles: Sage Publications.

- Crittenden, Ann (2001): The price of motherhood. Why the Most Important Job in the World is Still the Least Valued. New York: Henry Holt \& Co. 
- Dentitth, Audrey y Brady, Jeanne (2001): "Critical Voyages: Postmodern Feminist Pedagogies as Liberatory Practice”. En: Teaching Education, vol. 12, no 2, pp. 165-176.

- DESCO - Centro de Estudios y Promoción del Desarrollo (1992): Pautas y prácticas de Crianza de Niños de 0 a 6 años de Zonas Urbano-Marginales y Rurales. Lima: Unidad de desarrollo y proyectos.

- Fagan, Honor (1991): "Local Struggles: Women in the Home and Critical Feminist Pedagogy in Ireland” En: Journal of Education, vol. 173, nº 1, pp. 65-75.

- Flax, Jane (1997): "Postmodernism and Gender Relations in Feminist Theory". En: Sandra Kemp y Judith Squires (ed.): Feminisms. Oxford: Oxford University Press, pp. 170-180

- Foro Educativo y Consorcio de Universidades (2001): La Universidad en el Perú: Desafíos y Preguntas. Lima: Foro Educativo y Consorcio de Universidades.

- Garcia, Maria (2008): "The Impact of Program Experiences on the Retention of Women Engineering Students in Mexico". PhD dissertation, Texas University, [en línea] Disponible en: http://repository.tamu.edu/bitstream/handle/1969.1/ETD-TAMU-2008-12210/VILLA-DISSERTATION.pdf?sequence=1 [10/01/2013].

- Gouthro, Patricia (2002): "What counts? Examining Academic Values and Women's Life Experiences from a Critical Feminist Perspective”. En: The Canadian Journal for the Study of Adult Education, vol. 16, nº 1, pp.1-19.

- Hidalgo, Liliam (2004): "Cuatro Ventanas para Mirar la Escuela Rural Andina en el Cusco”. En: Tarea Revista de Educación y Cultura, vol. 59, nº 11, pp. 29-34.

- Kalil, Ariel y Danziger, Sandra (2000): "How Teen Mothers are Faring under Welfare Reform”, [en línea] Disponible en: http://www.fordschool.umich.edu/research/pdf/kalil_2_03_00.pdf [10/01/2013].

- López, Francisco (2007): "Notas para un estudio comparado de la educación superior a nivel mundial". CLACSO, [en línea] Disponible en: http://bibliotecavirtual.clacso.org.ar/ar/libros/campus/segrera/03LSegrera.pdf [10/01/2013].

- Macedo, Beatriz (2003): "Secondary Education in Rural Areas". Oficina Regional de Educación para América Latina y el Caribe UNESCO-Santiago, [en línea] Disponible en: http://unesdoc.unesco.org/images/0016/001611/161192e.pdf [10/01/2013].

- McFarlane, Seth; Beaujot, Roderic and Haddad, Tony (2000): "Time Constraints and Relative Resources as Determinants of the Sexual Division of Domestic Work". En: Canadian Journal of Sociology, vol. 25, nº 1, pp. 61-82.

- Montaño, Sonia (2007): "El Sueño de las Mujeres: Democracia en la Familia". En: Irma Arrigada y Verrónica Aranda (ed.): Cambio de las Familias en el Marco de las Transformaciones Globales: Necesidad de Políticas Públicas Eficaces. Serie Seminarios y Conferencias, n 42. CEPAL/UNFPA, Santiago de Chile, pp. 139-143. 
Socio-educational experiences and gender dynamics among young mothers attending college

- Montero, Carmen y Tovar, Teresa (1999): Agenda Abierta para la Educación de las Niñas Rurales. Lima, CARE-Perú: Instituto de Estudios Peruanos y Foro Educativo.

- Myers, Robert (1994): Estudios de prácticas de crianza. Contexto general. Colección Prácticas de Crianza. Bogotá: CELAM, UNICEF y SELAC.

- Niddifer, Jana and Bashaw, Carolyn (2001): Women Administrators in Higher Education: Historical and Contemporary Perspectives. Albany, NY: State University of New York Press.

- Stalker, Joyce (2001): "Misogyny, Women, and Obstacles to Tertiary Education: A Vile Situation". En: Adult Education Quarterly, vol. 51, nº 4, pp.288-305.

- Stromquist, Nelly (1992): Women and education in Latin America. Knowledge, Power, and Change. Boulder: Lynne Rienner Publishers.

- Tisdell, Elizabeth (1995): Creating inclusive adult learning environments: Insights from multicultural and feminist pedagogy. Columbus: ERIC Clearinghouse on Adult, Career, and Vocational Education. The Ohio State University.

- UNESCO (1998): "Higher education in the twenty-first century". Thematic Debate, [en línea] Disponible en: http://unesdoc.unesco.org/images/0011/001166/116618m.pdf [10/01/2013].

- Universia (2005): "Feminización en la Educación Superior", [en línea] Disponible en: http://sitios.universia.edu.pe/noticias/principales/destacada.php?id=41954 [10/01/2013]. 